\title{
Revolt Among the Cabbage Heads
}

He lived in the belly of a golden furnace, and every morning he would collect his charred teeth and string them through their cavities into a necklace. Then he would speak at us all in whalespeak and reek conspicuously of sea water.

We despised him for his ecumenical airs.

"Am I not the sun?" he would say, skulking with his painted chieftain cheekbones. Then he would die with that toad-lipped gasp, his eyes becoming pebbles in puddle bottoms, black and glassy through the ripples of our tears.

Blood would spill out, orange and ochre, making a rouged corpse of our landscapes.

He made janitors of all of us this way. And just as quickly he was born again, tooth necklace rattling, sucking wind through the harmonica of his gums.

"Am I not the sun?"

But when she came there was a great hole to fall into.

Everything in her was an echo.

We were in love with the night for what we could tumble through. In her silver chambers she would recline like a doll, her mouth, that delicate $\mathrm{O}$, unclosing, waiting for us to put what we were inside it. We had many words in her until he returned, until his bony fingers parted her lips, his gaze like a shellac as he opened her. 
We stood steady as pews.

We stood with our bodies buried underground, our cabbage heads in her moonlight.

The words rolled out of her, across her still tongue, those words so familiar to us.

And we sat silenced with bitterness, the subjects of another dawning, as he smiled like he'd just harrowed hell, turning toward us with his brilliantine regards.

Inside us, the green things stirred their engines.

"Am I not the sun?" he said, taking back the words from her lips like a young bird.

How had we come to speak his shame song? We stared at her, so dead, beautiful as a shadow dampening the ground.

We did not weep. We did not move.

We watched him limp his broom legs over the hill, and he was gone. 